\title{
The challenge before the fight: a discussion on rapid weight loss in UFC Athletes El desafío antes de la pelea: una discusión sobre la pérdida de peso rápida en los atletas de UFC
}

\author{
Riqueldi Straub Lise, Mayara Torres Ordonhes, André Mendes Capraro, Fernando Renato Cavichiolli \\ Universidade Federal do Paraná (Brazil)
}

\begin{abstract}
This study analyzed some cases of rapid weight loss procedures in Mixed Martial Arts (MMA) and athletes linked to the Ultimate Fighting Championship (UFC), currently the largest promoter of the sport. Therefore, printed sources were used, such as specialized magazines or not; documentaries, television programs, interviews, articles on websites; documentary sources, regulations and protocols. It was noted that the rapid weight loss represents overconformity deviances, which are part of a code of conduct valued by athletes, but sometimes become problematic. The cases listed here obtained relative repercussions in the media and resulted in acute damage to the athletes, financial and marketing damage to the event promoter. There was also a certain malpractice among athletes and teams, event organizers, and the North-American Athletic Commissions to try to prevent extreme procedures for rapid weight loss from occurring more often by putting athletes at risk, causing damage to the event itself.
\end{abstract}

Keywords: Mixed Martial Arts; Ultimate Fighting Championship; Rapid weight loss; Combat sport; Overconformity Deviances.

Resumen: El presente estudio analizó algunos casos de procedimientos de pérdida de peso rápida en atletas de Artes Marciales Mixtas (MMA) vinculados al Ultimate Fighting Championship (UFC), actualmente el principal impulsor de este deporte. Por tanto, se utilizaron fuentes impresas, como revistas especializadas o no; documentales, programas de televisión, entrevistas, artículos en sitios web; fuentes documentales, normativas y protocolos. Se observó que la pérdida rápida de peso se configura como una desviación supraconformativa que forma parte de un código de conducta valorado por los deportistas, pero que en ocasiones se vuelve problemático. Los casos aquí enumerados obtuvieron relativa repercusión mediática y resultaron en daños agudos y crónicos a la integridad física de los atletas, pérdidas económicas y de mercado para el promotor de los eventos. Se observó que existía un cierto descuido entre los atletas y equipos, organizadores de eventos y comisiones atléticas norteamericanas para tratar de evitar que los procedimientos extremos para la pérdida rápida de peso ocurran con mayor frecuencia, poniendo en riesgo a los atletas y causando daños al evento en sí.

Palabras clave: Artes marciales mixtas; Ultimate Fighting Championship; Pérdida de peso rápida; Deporte de combate; Desviaciones supraconformativas.

\section{Introduction}

In 1997 - as required by the North-American Athletic Commissions - the UFC organizers first set up divisions by weight. At this time, only two weight classes were set, the lightweight, with athletes weighing up to 90 kilograms, and the heavyweight, over 90 kilograms. In 2001, UFC already had five categories, currently there are eight male and four female weight classes (Podhurskyi \& Pavlenko, 2020; UFC, 2019).

The division by weight classes proved to be a great advance, aiming to provide equal sports conditions among the athletes (Elias \& Dunning, 1992), thus avoiding the absurds that occurred in the first editions

Fecha recepción: 21-09-21. Fecha de aceptación: 01-12-21

Mayara Torres Ordonhes

mayaraordonhes@hotmail.com during the years 1993 and 1994, when UFC was still considered an intermodality event (UFC - celebreties and classics, 2017). But the successive introduction of new weight classes also corresponded to marketing interests. Events whose cards have title contests tend to attract more public attention and therefore sell more. Thus, in 2018, 39 editions of the UFC were held, in 13 there were belt disputes, i.e., this occurs in one third of the events (Combate.com, 2019).

When only two weight classes were set up, there was an almost natural classification of the athletes into the established categories. However, with the insertion of new classes and increasing competitiveness, it has become increasingly common for fighters to make radical effor ts to stay in their categories or even decrease their body weight to fight in lighter classes.

The athletes' intention to lower their body weight and to shift to a lighter weight class is based on the logic 
of fighting against physically weaker opponents (Artioli, Franchini \& Lancha Junior, 2006), thus increasing the possibility of winning. However, weight loss procedures have become so common among fighters that athletes today lower their weights to fight on an equal term against their opponent, who has also lost weight to the match. According to Lorenço-Lima \& Hirabara (2013), there are two alternatives for the pre-competitive weight loss process. The first is called weight loss, which suggests that athletes undergo moderate food restriction in the high-protein diet and adequate carbohydrate intake. Weight loss significantly reduces body weight as well as fat percentage. If used for a period of two weeks, weight loss does not cause any reduction in performance or even physiological changes, however, this procedure is rarely used by athletes in the pre-competitive period. The other, much more widely used alternative is called rapid weight loss, which consists of several distinct procedures such as «severe food restriction; performing intense exercises; dehydration achieved by restricting fluid intake, using sauna and training in warm environments» (Artioli et al., 2006, p.93).

Typically, such procedures last about three weeks and, in the days before weighing, caloric intake can be reduced to $500 \mathrm{kcal}$ per day and fluid intake is suppressed (Lorenço-Lima; Hirabara, 2013). The aggravating fact is that some athletes use several of these methods simultaneously, endangering their physical integrity. The use of rapid weight loss may cause the following physiological changes: «[...] increased GH and decreased testosterone; decreased renal blood flow and glomerular filtration volume; increased loss of electrolytes; decreased immune system activity» (Artioli et al., 2006, p.95). Most of the methods used by athletes undergoing rapid weight loss are directed to the severe dehydration. The consequences on the performance of the fighters were: reduction in muscle strength, anaerobic power and aerobic capacity, alteration in the glycemia maintenance capacity, among others (Lorenço-Lima \& Hirabara, 2013).

In a survey with 179 male and female MMA athletes, Santos Junior (2016) points out that 100\% have already lost weight to participate in some competition and there was a high prevalence of rapid weight loss use. This study indicates that most athletes lose, on average, 8$12 \mathrm{~kg}$ (about 13\% body weight) in the pre-competitive period, within an average period of 20 days. However, there is a case where the fighter lost $33 \mathrm{~kg}$ before an event to reach the target weight (Santos Junior, 2016).

These numbers indicate that the use of rapid weight loss is a recurring practice among MMA athletes. The frequency of rapid weight loss use is directly related to the number of events a given athlete will participate in (Aloui et al., 2013). In the case of UFC, fighters play an average of three fights a year. Studies indicate that frequent repetition of rapid weight loss may cause the development of binge eating, decreased metabolic rate, which increases overweight gain and obesity (Santos Junior, 2016).

The RWL method is more used than weight loss because it provides a higher rate of weight loss; however, it presents higher risks of physiological impairment, whether for athlete's performance in competition or even for general health maintenance (Franchini, Brito \& Artioli, 2012; Aloui et al., 2013). However, weight loss due to severe dehydration requires a longer period of time for the body to regain normal hydration patterns, which can damage fighter's performance.

Certainly, the choice for rapid weight loss as well as the choice for the weight class in which a particular athlete will fight are not individual decisions. As a rule, MMA athletes are part of teams, and some members of these groups are instituted to intervene in this decision (Lise, 2018). In this sense, the coach, training colleagues, fitness coach, older fighters, nutritionist and physician may interfere with the decision whether or not to use the RWL method (Santos Junior, 2016). It is also noteworthy that not all teams have regular monitoring of physicians or nutritionists. That is, in many cases, weight loss procedures, through dietary restriction and dehydration, are performed empirically and under the guidance of unqualified people who may be unaware of the potential risks of this method.

Rapid weight loss represents a physiological challenge for fighters, however, even with negative evidence, it remains a widely used resource (Franchini et al., 2012; Aloui et al., 2013). Although this type of procedure is also noted in modalities such as boxing, judo, Taekwondo, Muay Thai and wrestling, according to Barley, Chapman and Abbiss (2017), it is the amateur and professional MMA practitioners who lose the most weight in the precompetitive period. As a rule, there is extensive media dissemination of cases related to rapid rapid weight loss, whose central theme mostly refers to the negative aspect and adverse consequences inherent to the use of this strategy, such as fight cancellations, emergency hospitalizations or even cases of death of fighters (Espn, 2014; BBC News, 2017; Law In Sport, 2018).

The centrality of the Ultimate Fighting 
Championship (UFC) for this research is because this organization is currently the largest MMA promoter in the world and the visibility of these events reaches considerable levels. According to Baldini Jr (2010), «Today's programming will be viewed by more than 430 million households in 147 countries, broadcast live in 19 languages, with 13 cameras and a hundred broadcast professionals».

Thus, the goal of this study was to analyze the weight loss procedures in athletes linked to the UFC, from some prominent cases. To this end, we intend to answer the following questions: why do athletes submit to this strategy? What are the consequences of using rapid weight loss for athletes and for the event and what measures are being taken in an attempt to prevent such procedures?

\section{Method}

In order to broaden the discussion on such occurrences, it would be a limiting factor here to adopt a single typology of material of analysis, otherwise it would limit the scope of the research. Thus, we performed a wide selection of materials, whose purpose is based on a diversified understanding of the phenomenon. Therefore, printed sources were used, such as specialized magazines or not; documentaries, television programs, interviews, articles on websites; documentary sources, regulations, protocols, among others.

Out of the 33 surveys pre-listed to prepare this article, only four specifically addressed MMA; the other 26 surveys were centered on rapid weight loss, but in the context of other combat sports such as judo, jiujitsu, Muay Thai, Tae-kwon-do, Olympic wrestling and boxing. Three articles made reference to combat sports in general. This clarification implies the recognition that the rapid weight loss method is a resource widely used by combat sportsmen of various modalities.

Regarding the theoretical framework adopted in this study, we chose the constructs advocated by Jay Coakley (2007) in the work «Sports in Society: issues and controversies», especially on the concept of overconformity deviance, which is understood by athletes as a «desirable code of conduct» even if in certain circumstances such a «code» results in some harm to the physical integrity of the sportsman.

The cases reported here were selected from the media repercussion and also by the negative consequences caused by the rapid weight loss, both for the athlete and for the UFC event. Although it is known that rapid weight loss is widely used in other MMA events, in this particular case only those related to UFC athletes are addressed.

\section{Results}

There is no doubt that rapid weight loss and dehydration are sacrificing and risky, but as previously mentioned, this is a joint choice (Camilo \& Furtado, 2017). The confidence an athlete has in his/her coach and the certainty that the coach wants and can make him/her a champion encourages excess efforts such as the decision to shift down one or two weight classes, even if this will damage the athlete's health (Franchini et al., 2012; Aloui et al., 2013).

Situations analogous to this were theorized by Jay Coakley (2007), based on what he established as overconformity deviance. It consists of ideas and actions that indicate uncritical acceptance of norms and failure to recognize boundaries to follow them, reflecting a social condition that exists when overconformity spreads and creates unlimited obedience to leaders' norms or commands. Importantly, this kind of deviance involves abnormal ideas and actions related to strict compliance with the rules, even if they are harmful.

Regarding sports, the modes of overconformity deviance, identified in sports, mostly refer to injuries from overtraining, extreme weight control strategies, competition when injured, in short: it reflects what Coakley (2007) calls as the «athletes code». Such a code, related to sacrifice and dedication, must be fulfilled albeit through extreme measures that may compromise welfare - for peer acceptance. It is this need for socialization, from acceptance, that creates the conditions for athletes to tend to overconform to the norms set forth in the code or ethics of sports, especially combat sports.

Although rapid weight loss is considered a reckless method, there is no doubt about its effectiveness. That is, athletes who are available to the sacrifices of such procedures can usually achieve their goals, falling into the desired category. As already pointed out, such a method is aimed solely at success on the weighing scale; on the other hand, this resource should not impair the athlete's performance in the fight, but this is not always possible due to the large water deficit.

Even though MMA athletes have around 24 hours to restore normal hydration patterns, so that their performance is not impaired, studies indicate that this 
time is not enough. The research by Jetton et al. (2013), which analyzed the rehydration process in $40 \mathrm{MMA}$ athletes who underwent the rapid weight loss method, points out that 39\% still had a significant dehydration, two hours before the fights. Possibly, these athletes had their performances impaired during the competition.

Lately, news of MMA athletes who have experienced extreme dehydration, including risk of death, have become more frequent (Alderman, Landers, Carlson \& Scott, 2004; Franchini et al., 2012). In the early hours of July 8, 2016, UFC 200 weigh-in day, an event in which the female bantamweight title would be disputed between the American Miesha Tate and the Brazilian Amanda Nunes, Tate presented a severe dehydration due to the need to lose a few kilograms before the official weigh-in (Ultimato, 2016). The situation shows that the process of water loss was not accompanied by physicians or nutritionists, which confirms Santos Junior (2016) research on the monitoring of specialized professionals during such procedures.

The afternoon before the weigh-in, Tate posted a photo on social media in which she claimed to be 146 pounds, around 66 kilograms, that is, by the time of weigh-in, the athlete would have to lose another 5 kilograms, approximately $7.5 \%$ of all her body weight. In the official weigh-in event, Tate appeared extremely pale, dejected and without any facial expression, the fighter had to stand naked on the scale to reach the 61.2 kilograms, the upper limit of the category (Tatame, 2016). It should be noted here that in this period there were only two weight classes, strawweight (up to 52.2 kilograms) and bantamweight (up to 61.2 kilograms). This fact led the heavier fighters to an even greater sacrifice. In December 2016, the featherweight class (up to 65.8 kilograms) was instituted and, in December 2017, an intermediate class was created between the strawweight and bantamweight, called flyweight (from 52.3 to $56.7 \mathrm{~kg}$ ) (UFC, 2019). There are indications that the inclusion of new classes tends to soften weight loss among fighters.

Coakley (2007) agrees when he states that overconformity deviances become dangerous because they are not addressed. Quite the contrary: overconformity sounds like reaffirmation of dedication, hard work, and goal achievement given the difficulty of reaching the target weight. In the episode so far explored, Miesha has done her duty and all suffering is recognized by her peers.

On the night of the fight (about 24 hours after the weigh-in), then champion Miesha, considered a favorite in the match, performed apathetically and was easily beaten by the Brazilian fighter in just over three minutes of fighting. Possibly, the time to regain the ideal hydration pattern for the match was not enough and, it seems, this significantly impaired the fighter performance. Note that cases like this are increasingly common (MMA Junkie, 2019, 2013; MMA Mania, 2018; CBS Sports, 2016).

Another case with wide repercussions in the press was that of Renan Barão. On the morning of August 29, 2014, weigh-in day for UFC 177 - for which the bantamweight championship match was scheduled between Brazilian Barão and the AmericanT. J. Dillashaw - the Nova União team athlete had to be hospitalized. In that morning, Barão underwent severe dehydration procedures in the hotel room where he was staying with André Pederneiras, the team leader, and some members. The Nova União press office issued an official note entitled «Nova União Fighter was quickly cared for and is well recovered from the shock», in which it tries to clarify what happened.

This official note again informs that the rapid weight loss procedures were not assisted by physicians or nutritionists, as the first aid provided to Barão came from the coach. In a way, this note attempts to minimize the severity of the situation, referred to as a «shock». The way the note was written seems to imply that Barão fainting was caused by the shock to his head and not as a result of the dehydration process. The description of the weight loss method is referred to in the note as «normally going down in weight», which can be understood as the use of rapid weight loss is commonplace. The athlete, unconscious was taken by ambulance to the hospital and only recovered the senses after the intravenous fluid replacement, indicating that the fainting was caused by severe dehydration (PM Jucurutu, 2014). The physicians who provided emergency care to the fighter contacted the medical board of the event, informing the athlete's clinical situation. Aware of the athlete's health, the event organizers immediately canceled this match (Espn.com.br, 2014).

It was not the first time that Barão had faced problems with weight loss, in two other situations the Brazilian athlete had already presented himself for the official UFC weigh-in above the weight class limit (61.2 kilograms). According to the Veja.com website. «For the rematch, Barão changed his weight loss strategy over the last fight, instead of starting his diet ten days before the fight, he decided to change his eating habits 
just four days before the event» (Veja.com, 2014). It is unclear how much weight Barão had already lost in the dehydration process, but some reports claimed that the athlete was only 700 grams far from the limit, although this information also seems to be much more likely to alleviate the situation (Graciemag, 2014).

Another case with a significant media exposure mentioned UFC athlete Nicco Montaño. Called to defend the belt for the first time, the flyweight champion Montaño had serious problems with the weight loss. One day before the fight against Valentina Shevchenko, the American athlete's team requested emergency care from UFC medical staff. The organization's physicians immediately stopped the dehydration process by finding that Montaño had severely impaired kidney function due to the rapid weight loss procedure (Combate.com, 2018). The fighter was taken from the hotel and admitted to a medical center near the site of the event, where she was hospitalized for two days. The fight for the title was canceled and the UFC decided to remove the belt of the then champion (Combate.com, 2018). Former UFC strawweight champion Joanna Jedrzejczyk gave her opinion on the removal of the Montaño belt as follows: «Weight loss is not easy, not cool, but you have to be at weight when you need it» (Combate.com, 2018).

Joanna Jedrzejczyk's statements are related to sports ethics and overconformity deviance, since it refers to an interrelated set of rules or standards used to guide and evaluate ideas, traits and actions in a social world in this case, the sport world. Formed by four standards: 1) athletes are dedicated to «the match» over all other things; 2) athletes fight for distinction, winning symbolizes improvement and establishes distinction; 3) athletes accept risks and play with pain; and finally, 4) athletes do not accept obstacles in the pursuit of success in sports (Coakley, 2007). It is based on this ethic, above all, that athletes strive for overconformity without perceiving it as a deviance.

\section{Discussion}

It was not the intention to produce here an exhaustive inventory of all cases of clinical complications triggered by rapid weight loss, these three cases are already sufficient to draw some conclusions even partially. In the three cases listed, we can see the absence of qualified professionals to make the method of rapid weight loss less risky for athletes, i.e. the procedures are performed empirically, on an experimental basis, based on rudimentary information about nutritional requirements and physiological damage related to such a method. In all the situations mentioned, there was the consent of the athlete - who was possibly partially aware of the risks pertinent to the use of this procedure - the support of the training colleagues and the prescription and consent of the coaches and leaders. Even after hundreds of cases with these same outcomes, this method is still widely used, there seems to be a tacit acceptance by all combat sportsmen, including MMA fighters, of the need to lose weight before a fight. If this stimulus comes from within the gyms, what would be the resources to at least try to alleviate this problem?

The rapid weight loss method poses an acute and chronic health threat to athletes, however, the potential damage caused by the use of RWL goes beyond those possible. There are also financial losses resulting from the cancelation of matches according to the case of Renan Barão or Nicco Montaño and losses to the entire sports chain, as occurrences of this nature cause negative repercussions and tend to drive away sponsors interested in investing in MMA.

Aware of the damage and negative repercussions listed above, fight event organizers, especially the UFC, have made a commitment to try to restrict the use of rapid weight loss. The first steps taken in this regard mention the financial support athletes receive. In the UFC, if an athlete fails to reach the target weight class on the day of weighing, he/she instantly loses $20 \%$ he/ she would originally receive and this money is passed on to his/her opponent. In case of cancellation of the match, the athlete who fails to reach the required weight will not be entitled to the financial support, only his/ her opponent, if he/she is within the class limit (Venum, 2015). However, this measure was unable to inhibit coaches and athletes; on the contrary, it made the process of rapid weight loss even more dramatic by the imminence of losing large amounts of money. Another measure was more authoritarian, the UFC organizers forced some athletes, who were known to have difficulty reaching the target weight, to step up to a higher weight class (Combate.com, 2019). This was the case of Renan Barão who, in order not to be banned from the event, step up from bantamweight (61.2 kilograms) to the class immediately above, featherweight (65.8 kilograms) (Albuquerque; Marinho, 2019). There is also a kind of veiled norm - which is not in the sporting regulations but is somewhat employed - in which the athlete who exceeds the weight limit on the weigh-in day three times is automatically banned from the event. 
Two other attempts to control this problem have a less arbitrary character. The first of these is the prohibition of intravenous fluid replacement, in other words, the use of saline as a means of replacing body fluids, a technique widely used in the rehydration process after weighing. This rule was drafted in a partnership that UFC established with the U.S. Anti-Doping Agency (USADA) and came into effect on October 1, 2015 (Albuquerque; Rodrigues; Russio, 2015).

Formerly treated as a common method of rehydration, now with new water legislation has become part of the set of procedures prohibited by USADA (doping) (Albuquerque, Rodrigues \& Russio, 2019). Tests have been developed that can detect this type of rehydration, and athletes who are caught using this method can be suspended for up to one year and, in case of recurrences, may even be banned from the sport (García-Grimau, Casado \& de la Vega, 2020; Albuquerque, Rodrigues \& Russio, 2019). However, what was perceived with the ban on intravenous rehydration was a noticeable drop in fighter performance.Through television broadcasts, it was noted that many athletes were extremely fatigued at the end of the first round of combat, which was unusual until then.

This shows that the vast majority, if not all of the UFC fighters, used the intravenous fluid replacement. Certainly, this drop in the show quality worried the event organizers, who made a subtle but significant change in the weigh-in protocols, allowing a longer time for oral rehydration of athletes who use rapid weight loss, as will be seen below.

The other, more complex and controversial attempt is still under study. UFC and USADA are intending to implement the «Weight Management Policy», in which, «[...] fighters will have to prove, in the week of the fight, that they are no more than $8 \%$ overweight they need to reach in the weigh-in» (Uol Esporte, 2016). According to this directive, athletes must be on the week of the event with an excess weight, beyond the class limit, of at most $8 \%$ body weight. That is, an athlete wishing to fight in the lightweight class (70.3 kilograms), seven days before the weigh-in, cannot weigh more than 76 kilograms. Thus, by the time of weighing, the athlete would have to lose about 800 grams per day to reach the maximum limit of the class. Undoubtedly, this would mean a significant advance in trying to prevent athletes from using the rapid weight loss method, with three or four days to go before official weigh-in. There are still, under study, the proposal to establish protocols that determine the weight of the athlete and in which class he/she should fight, based on his/her body characteristics, although this seems utopian.

Although the UFC has implemented rules and studied new possibilities to prevent rapid weight loss procedures, especially dehydration processes, another recent measure seems to go against these new policies and tends to facilitate the oral rehydration procedure.

The UFC weigh-in events over the years have become increasingly show-off. These days they are configured as an event almost in proportion to the main event. With ticket sales, live TV broadcasting and enabling the public to interact with the fighters. Weighin serves as a kind of pre-fight, but this time against the scale, hence the idea of calling this study «The Challenge Before the Fight». To illustrate this spectacle, in UFC 198, held in Curitiba on May 14, 2016, all 15,000 weighin tickets were marketed in advance, setting an audience record (Linares \& Resende, 2016).

Until the UFC 199 edition, there was a specific protocol for weighing. Usually, 24 hours before the main event, the two athletes of the first fight of the event were called on stage one by one and stepped on the scale, the weight of each of them being announced to the public, the two approached, stared at each other and left the stage. This was repeated in succession until the two opponents of the main fight were called. End of weighing, start of weight recovery process, rehydration, still on the weigh-in stage. The scale used in this show was official and checked by the Athletic Commissions responsible for the standardization of the event, and the weighing was really public. If any fighter exceeded the weight predicted for his/her category, the public would know at that moment, there was still an hour's break for the athlete who could not reach the target weight the first time to make a second attempt (Dantas, 2016).

This detailed description serves to demonstrate the fact that the official weigh-in and the related event took place at the same time and were public. With the modification of the UFC protocols, since the 199th edition, the official weigh-in has become private, closed to the public and the press. Now the scale officialized by the Athletic Commissions is based in the hotel where the athletes are staying. The scale is available from 10 am until $2 \mathrm{pm}$ the day before the main event, and now the fighters have only one attempt to reach the weight class limit, this whole process is only accompanied by the delegates of the Athletic Commissions (ESPN, 2016).

The change seems to be subtle, but in some ways, it can help athletes continue to perform the rapid weight 
loss procedure. This is because this new protocol allows fighters more time to perform the oral rehydration process, now the only one allowed. If before the fighters were about 27 hours apart between weigh-in and the match, they can now be up to 33 hours apart. It may seem little, but this change was very well received by most fighters. Former UFC middleweight title holder Michael Bisping stated: «I will use this advantage of weighing at 10 am simply because I will have more time to rehydrate. Makes sense. My opponent will do the same thing, so there is no advantage, I just believe that for fighters in general this will be much safer» (Rodrigues, 2016).

Bisping's statement is somewhat biased and ambiguous. By announcing that this protocol change will not be of advantage to him over his opponent, he is right. But by admitting that it will be advantageous to have more time to rehydrate, he is implicitly recognizing that this change will benefit all those who adopt rapid weight loss as the usual procedure. At this time, where the UFC takes steps to prevent rapid weight loss methods, this change in the weigh-in protocol seems to be contradictory.

Throughout this study, we dealt mainly with aspects related to rapid weight loss in MMA athletes. Nevertheless, the methodological approach may give the false impression that rapid weight loss procedures and their consequences are a problem exclusive to this modality. This is unfounded.

To illustrate this statement, in research by LorençoLima \& Hirabara (2013), which deals with the effects of rapid weight loss on combat athletes, there are reports of three deaths of healthy American high school and Olympic wrestlers only in 1997, these deaths were caused by cardiopulmonary arrest due to the severe process of rapid weight loss. In order to try to prevent further deaths, the National College Athletic Association (NCAA) has implemented some regulatory modifications in an attempt to prevent the frequent use of this method (Alderman et al., 2004).

Foxcatcher: a story that shocked the world (2014) shows Mark Schultz - a 1984 Los Angeles Olympics Gold Medalist and world champion in wrestling - in one scene using the rapid weight loss method before an important competition. After a bulimic episode, due to pressure from pseudo coach John Du Pont, the protagonist needed to lose about 6 kilograms in a few hours. With his brother's support, he used unorthodox strategies: vomiting and aerobic exercise in heavy clothing to dehydrate. Indeed, he managed to reach the target weight of his class, but soon after weighing, naked, passed out in the arms of his brother (Foxcatcher, 2014).

Given all the problems related to rapid weight loss, the California State Athletic Commission has put forward a bold proposal containing ten items that can dramatically reduce the risks posed by the use of reckless methods. In May 2017, the proposal was unanimously approved by the members of the referred Athletic Commission, and in July 2017, it became effective (Combate.com, 2017).

These new regulations contain important items, which, if implemented, can be a very effective form of combat against risky methods of rapid weight loss. The fifth item of the resolution alone would be a possibility of preventing athletes from insisting on the method of rapid weight loss, given that, in the second failure of the desired weight class, the athlete would automatically step up to a higher class. Item 7 , on the other hand, consists of a second weigh-in in the period immediately prior to the fight, if it is observed that the athlete recovered with hydration more than $10 \%$ body weight, as item 5 , he/she will step up to an upper weight class. Item 9 requires athletes to use weight loss methods to the detriment of rapid weight loss, once it is difficult for an athlete to maintain the dehydration process for a period of more than ten days (Combate.com, 2017), due to the loss of physical abilities acquired during the training. This proposal is viable from a financial point of view, as the agents of the Athletic Commissions periodically collect anti-doping samples of the fighters, it would be sufficient to have a scale approved by the institution responsible (Combate.com, 2017).

Until February 2018, this proposal came into force only in the State of California, given the autonomy of the North-American Athletic Commissions to adopt their own criteria to try to reduce rapid weight loss methods. Other Athletic Commissions are awaiting the results of this resolution to adopt or not such criteria. As an example, at UFC Fight Night: Swanson vs. Ortega held on December 9, 2017 in Fresno, California, four athletes - Marlon Moraes, Iuri Alcantara, Davi Ramos and Luke Sander-had a recommendation to step up to a higher weight class, as they exceeded the $10 \%$ difference between the official weigh-in, the day before the fight, and the pre-fight weigh-in (Ag Fight, 2017).

From the date of the event, athletes have a deadline to submit results of exams issued by physicians accredited by the California Athletic Commissions, in which there must be certification that the athlete's chosen weight class is appropriate. Without this 
certification the athlete will be prevented from fighting in the same class that generated the recommendation, thus having to step up to a higher weight class (Ag Fight, 2017). However, there is still doubt as to whether the recommendation will be valid only in the State of California or if other jurisdictions will comply with such a decision, even if they have no similar regulations. No other Athletic Commission has commented on this case.

\section{Conclusion}

Although not a recent practice, weight loss procedures have been widely used by boxing, judo or Olympic wrestling athletes, with the primary goal of gaining the advantage of fighting a lighter opponent. However, given the spectacle nature of UFC, there has been recurring news reports in which many athletes linked to this event have been highly dedicated to rapid weight loss and end up being victims of the risks and problems caused by such procedures.

It is known that the decision for severe dehydration processes is not always made spontaneously by the athletes, who are sometimes influenced or even coerced to shift down to a lighter weight class. While research suggests that this procedure, in extreme cases, may impair the athlete performance or even impair his/her health, on the other hand, the cases listed here confer that this practice is part of the training to be a fighter, a routine of that profession.

So far, such procedures are not yet a rule violation, however, due to cases of hospitalization, fight cancellations, and the imminent possibility of death, some agencies are taking steps to prevent the use of rapid loss of procedures, especially those referring to dehydration. What was observed in this study, however, is that the UFC has taken contradictory measures to prevent such procedures. While some of them - ban on intravenous rehydration - are indicative that the organization intends to prevent such a strategy, it also allows athletes more time to rehydrate, encouraging athletes to continue losing weight through dehydration.

The fact that this study specifically addressed a single event promoting Mixed Martial Arts, the Ultimate Fighting Championship, can be characterized as a limitation. In this sense, it is recommended the academic community to continue the discussion in other MMA promoting franchises or even in other combat sports.

\section{Acknowledgements}

This study was carried out with the support from the Coordination for the Improvement of Higher Education Personnel - Brazil (CAPES) - Financing Code 001.

\section{References}

Albuquerque, A. \& Marinho, R. (2019). Com quatro derrotas seguidas, Renan Barão ganha nova chance e encara D’Silva no UFC SP. Combate.com 02 Oct. 2019. Retrieved from: https://sportv.globo.com/site/ combate/noticia/com-quatro-derrotas-seguidasrenan-barao-ganha-nova-chance-e-encara-dsilva-noufc-sp.ghtml.

Albuquerque, A. \& Rodrigues, E.; Russio, M. (2019). Dirigente explica proibição do soro e regras da política antidoping do UFC. Combate.com, 25 Aug. 2015. Retrieved from: http://sportv.globo.com/site/ combate/noticia/2015/08/dirigente-explicaproibicao-do-soro-e-regras-da-politica-antidopingdo-ufc.html.

Alderman, B. L., Landers, D. M., Carlson, J. O. H. N., \& Scott, J. R. (2004). Factors related to rapid weight loss practices among international-style wrestlers. Medicine and science in sports and exercise, 36(2), 249. 252. https: / / doi.org/10.1249/ 01.MSS.0000113668.03443.66

Aloui, A., Chtourou, H., Hammouda, O., Chaouachi, A., Chamari, K., \& Souissi, N. (2013). The challenge of rapid weight loss prior to competition for Muslim combat sport athletes during Ramadan. Biological rhythm research, 44(6), 876-884. https://doi.org/ 10.1080/09291016.2013.780698

Artioli, G. G., Franchini, E., \& Lancha Junior, A. H. (2006). Perda de peso em esportes de combate de domínio: revisão e recomendações aplicadas. Revista Brasileira de Cineantropometria \& Desempenho Humano, 8(2), 91-101. Retrieved from:https:// periodicos.ufsc.br/index.php/rbcdh/article/view/ $3887 / 16676$

Ag Fight. (2019). Comissão Atlética pede que três brasileiros subam de categoria no UFC. 30 Dec. 2017. Retrieved from: https://www.uol.com.br/esporte/ultimasnoticias/ag-fight/2017/12/30/comissao-atleticapede-que-tres-brasileiros-subam-de-categoria-noufc.htm?cpVersion=instant-article.

Barley, O. R., Chapman, D. W., \& Abbiss, C. R. (2018). Weight loss strategies in combat sports and concerning habits in mixed martial arts. International journal of sports physiology and performance, 13(7), 933939. https: / /doi.org/10.1123/ijspp.2017-0715 
Baldini Jr., W. (2019). UFC cresce e se torna negócio bilionário. 07 ago. 2010. Retrieved from: http:// www.estadao.com.br/estadaodehoje/20100807/ not_imp591693,0.php.

BBC News (2019). 'Not far from death': How fighters are risking their lives to make weight. 14 March 2017. Available at: https://www.bbc.co.uk/ bbcthree/ article/a4372439-aef4-4f18-bd9ad914e3f37f2a.

Camilo, J. A. de O, \& Furtado, R. N. (2017). Doping e a lógica da escolha. Athenea Digital. Revista de pensamiento e investigación social, 17(1), 23-41. http: / /dx.doi.org/10.5565/rev/athenea. 1670.

Coakley, J. J. (2007). Sports in society: Issues \& controversies.

Combate.com. (2019). Joanna apoia decisão do UFC de retirar cinturão de Nicco Montaño: «Foi justa». 16 set. 2018. Retrieved from: https://sportv.globo.com/ site/combate/noticia/joanna-apoia-decisao-do-ufcde-retirar-cinturao-de-nicco-montano-foijusta.ghtml.

Combate.com. (2019). Comissão aprova novas regras para corte de peso e cria mais 4 categorias. 17 May. 2017. Retrieved from: http://sportv.globo.com/site/ combate/noticia/2017/05/comissao-aprova-novasregras-para-corte-de-peso-e-cria-mais-4categorias.html.

Combate.Com. (2019,). Campeã dos moscas, Montaño está fora do UFC 228 após problema com corte de peso. 07 Sep. 2018. Retrieved from: https:// sportv.globo.com/site/combate/noticia/campeados-moscas-montano-esta-fora-do-ufc-228-aposproblema-com-corte-de-peso.ghtml.

Combate.com. (2019). Ganho excessivo de peso no UFC 241 pode fazer 13 atletas serem aconselhados a subir de categoria. 20 Aug. 2019. Retrieved from: https:// sportv.globo.com/site/combate/noticia/ganhoexcessivo-de-peso-no-ufc-241-pode-fazer-13-atletasserem-aconselhados-a-subir-de-categoria.ghtml.

Combate.com. (2019). Confira todos os resultados de cada evento do UFC em 2018. 01 Feb. 2019. Retrieved from: https: / /sportv.globo.com/site/combate/noticia/ confira-a-programacao-completa-do-ufc-noprimeiro-semestre-de-2018.ghtml.

CBS Sports (2016,). LOOK: MMA fighter weighs in a ridiculous 24 pounds overweight, can't believe it. Retrieved from: https://www.cbssports.com/ mma/news / look-mma-fighter-weighs-in-aridiculous-24-pounds-overweight-cant-believe-it/

Dantas, A. (2019,). UFC testará mudança no formato de pesagem antes das lutas. O Globo, 22 Jun. 2016. Retrieved from: https: / /blogs.oglobo.globo.com/ $\mathrm{mma} /$ post/ufc-testara-mudanca-no-formato-depesagem-antes-das-lutas.html.

Elias, N. \& Dunning, E. (1992). A busca da excitação no lazer. ELIAS, N.; DUNNING, E. A busca da excitação. Lisboa: Difel, 101-138.

ESPN (2014,). The Truth About MMA's Dangerous Weight Game. Available at: http:// www. espn.com/espnw/news-commentary/ article/11711953/the-truth-mma-dangerousweight-game.

ESPN. (2019). Entenda como funciona a 'pesagem de mentira' do UFC, que está chegando ao Brasil. 17 jun. 2016. Retrieved from: http:/ /www.espn.com.br/blogs/ espnmma/606923_entenda-como-funciona-apesagem-de-mentira-do-ufc-que-esta-chegando-aobrasil.

Espn.com.br. (2019). Barão não vê erro em perda de peso e diz que quer voltar logo para 'arrancar a cabeça' de Dillashaw. 31 Aug. 2014. Retrieved from: http:// www.espn.com.br/noticia/436525_barao-nao-veerro-em-perda-de-peso-e-diz-que-quer-voltar-logopara-arrancar-a-cabeca-de-dillashaw.

Foxcatcher: uma história que chocou o mundo. Direção: Bennett Miller. Produção: Bennett Miller, Megan Ellison, Jon Kilik, Anthony Bregman. Culver City, Califórnia (EUA): Sony Pictures, 2014, 1 DVD.

Franchini, E., Brito, C. J., \& Artioli, G. G. (2012). Weight loss in combat sports: physiological, psychological and performance effects. Journal of the international society of sports nutrition, 9(1), 52. https://doi.org/ 10.1186/1550-2783-9-52

García-Grimau, E., Casado, A., \& de laVega, R. (2020). Evolución de la investigación psicosocial del dopaje en el deporte de competición: una revisión narrativa (Evolution of doping in elite sport from the perspective of social sciences: a narrative review). Retos, 39, 973-980. https://doi.org/10.47197/ retos.v0i39.80834

Graciemag. (2019). Renan Barão e o corte de peso que o tirou do UFC 177. 30 Aug. 2014. Retrieved from: https: / /www.graciemag.com/2014/08/30/renanbarao-e-o-corte-de-peso-que-o-tirou-do-ufc-177entenda-o-caso/.

Jetton, A. M., Lawrence, M. M., Meucci, M., Haines, T. L., Collier, S. R., Morris, D. M., \& Utter, A. C. (2013). Dehydration and acute weight gain in mixed martial arts fighters before competition. The Journal of Strength \& Conditioning Research, 27(5), 1322-1326. 
https://doi.org/10.1519/JSC.0b013e31828a1e91. Law in Sport (2018). The dangers of weight-cutting in MMA: do we need an outright ban? Available at: https://www.lawinsport.com/content/sports/ item/the-dangers-of-weight-cutting-in-mma-dowe-need-an-outright-ban.

Lorenço-Lima, L., \& Hirabara, S. M. (2012). Efeitos da perda rápida de peso em atletas de combate. Revista Brasileira de Ciências do Esporte, 35(1). Available at: http://www.scielo.br/pdf/rbce/v35n1/a18v35n1

Linares, A.; Resende, I. (2019). UFC Curitiba quebra recorde de público em pesagem. 13 mai. 2016. Retrieved from: http://www.espn.com.br/noticia/ 598747_ufc-curitiba-quebra-recorde-de-publico-empesagem.

Lise, R. S. Cerceamentos, coerções e esportividade no Ultimate Fighting Championship (UFC). Retrieved from: https://www.acervodigital.ufpr.br/handle/ $1884 / 55782$.

MMA Junkie (2013). Dustin Poirier explodes on overweight Diego Brandao at UFC 168 weigh-ins. Available at: https://mmajunkie.com/2013/12/ dustin-poirier-explodes-on-overweight-diegobrandao-at-ufc-168-weigh-ins.

MMA Junkie (2019). John Lineker released from UFC contract after 16-fight tenure. Available at: https:/ /mmajunkie.com/2019/07/john-lineker-releasedufc-contract-16-fights.

MMA Mania (2018). Rousimar Palhares showed up 18 pounds overweight for grappling match with Craig Jones. Available at: https:/ / www.mmamania.com/ 2018/8/19/17755946/rousimar-palhares-showedup-18-pounds-overweight-for-grappling-matchwith-craig-jones.

Pessanha, K. (2019). Atleta de MMA, Leandro Feijão morre em dia de pesagem do Shooto 43. Combate, 26 Sep. 2013. Retrieved from: http://sportv.globo.com/site/ combate/noticia/2013/09/lutador-de-mmamorre-pouco-antes-de-pesagem-do-shooto-43.html.

Podhurskyi, S., \& Pavlenko, I. A. (2020). Enfoque diferenciado para el desarrollo de las capacidades de velocidad y potencia de atletas del boxeo tailandés teniendo en cuenta las categorías de peso (Differentiated approach to the development of speed-strength capabilities of qualified Muay-Thai Athletes. Retos, 40, 365-374. https://doi.org/ 10.47197/retos.v0i40.83499

Pm Jucurutu. (2019). Lutador Potiguar Renan Barão passa mal durante processo de perda de peso e está fora da luta do UFC. 29 ago. 2014. Retrieved from: http:// www.pmjucurutu.com.br/lutador-potiguar-renanbarao-passa-mal-durante-processo-de-perda-depeso-e-esta-fora-da-luta-do-ufc/.

Rodrigues, E. (2019). Lutadores do UFC 199 terão pesagem oficial 30 horas antes do evento. 01 jun. 2016. Retrieved from: http://sportv.globo.com/site/combate/ noticia/2016/06/lutadores-do-ufc-199-teraopesagem-oficial-30-horas-antes-do-evento.html.

Santos Junior, R. B. (2016). Perda de peso em atletas brasileiros de artes marciais mistas-MMA: prevalência, magnitude, métodos e sintomas vivenciados. https:// www.acervodigital.ufpr.br/handle/1884/44042.

Tatame. (2019). Vídeo: Miesha Tate sofre para bater o peso e precisa ficar nua para atingir limite da categoria; 9 jul. 2016. Retrieved from: http:// www.tatame.com.br/tatame/videos/videomiesha-tate-sofre-para-bater-o-peso-e-precisa-ficarnua-para-atingir-limite-da-categoria.

The Sports Daily. (2019). All-Time UFC PPV Sales Data. 16 jul. 2016. Retrieved from: http://mmamanifesto.com/ufc-ppv-data/ppv-main/all-timeufc-ppv-sales-data.html

UFC. (2019). Rankings. Retrieved from: https:// www.ufc.com.br/rankings.

UFC - Celebreties And Classics. (2019). First UFC KO ever - Gerard Gordeau vs Teila Tuli. 2017. Retrieved from: https://www.youtube.com/ watch? $\mathrm{v}=\mathrm{GL} 86 \mathrm{jp} 8 \mathrm{txs} 0$

Ultimmato. (2019). Site revela imagem de Miesha Tate sofrendo com corte de peso antes de luta. $14 \mathrm{Jul}$. 2016. Retrieved from: http://sportv.globo.com/site/combate/ blogs/especial-blog/ultimmato/post/site-revelaimagem-de-miesha-tate-sofrendo-com-corte-depeso-antes-de-derrota.html.

Uol Esporte. (2019,). UFC implementará programa de controle de peso para proteger atletas. 13 mai. 2016. Retrieved from: http:/ / esporte.uol.com.br/mma/ ultimas-noticias / 2016/05/13/ufc-implementaraprograma-de-controle-de-peso-para-protegeratletas.htm.

Veja.com. (2019,). UFC 177: Renan Barão passa mal e está fora da revanche contra TJ Dillashaw. 29 ago. 2014. Retrieved from: https://veja.abril.com.br/ esporte/ufc-177-renan-barao-passa-mal-e-esta-forada-revanche-contra-tj-dillashaw/.

Venum. (2019). Perda de peso no MMA: o processo mais polêmico do esporte. 25 Feb. 2015. Retrieved from: https://venum.com.br/blog/perda-de-peso/. 